\title{
Ultrastructural study of sex inversion in a protogynous hermaphrodite, Epinephelus microdon (Teleostei, Serranidae)
}

\author{
S Bruslé-Sicard 1, L Debas 2, B Fourcault 1, J Fuchs 3 \\ 1 Université, Laboratoire de Biologie Marine, 66860 Perpignan; \\ 2 INRA, Laboratoire de Physiologie des Poissons, Campus de Beaulieu, 35042 Rennes; \\ 3 IFREMER, Centre Océanologique du Pacifique, BP 7004 Taravao, Tahiti, French Polynesia
}

(Received 17 January 1992; accepted 17 July 1992)

Summary - Sex inversion of Epinephelus microdon, a protogynous hermaphrodite was studied using light and electron microscopic criteria. The sex change takes place within ex-ovarian lamellae in which, in addition to spermatogonia, numerous primordial germ cells (PGCs) were detected. These undifferentiated and bipotential early germ cells are involved, as well as spermatogonia, in the building up of the testis.

\section{Epinephelus microdon / sex inversion / primordial germ cells / ultrastructure}

Résumé - Étude ultrastructurale de l'inversion du sexe chez un poisson hermaphrodite protérogyne, Epinephelus microdon (Téléostéen, Serranidé). L'inversion du sexe dEpinephelus microdon, hermaphrodite protérogyne, a été étudiée en microscopie photonique et électronique. Le changement de sexe s'effectue au sein des ex lamelles ovariques dans lesquelles, outre les spermatogonies, de nombreuses cellules germinales primordiales ont été identifiées. Ces cellules germinales précoces, indifférenciées et bipotentes, sont impliquées, tout comme les spermatogonies, dans l'édification du testicule.

\section{Epinephelus microdon / inversion du sexe / cellules germinales primordiales / ultrastructure}

\section{INTRODUCTION}

In many species of some families of teleosts, hermaphroditism and sex inversion constitute the normal type of reproduction (Atz, 1964; Chan and Yeung, 1983; Reinboth, 1983). Protogyny (sex inversion from female to male) seems fairly common in groupers as noted by Smith (1971). Epinephelus microdon is a small grouper living in the South Pacific. Little is recorded in the literature on the biology of this species apart from the preliminary report of Loubens (1980). The existence of protogyny in $E$ microdon was first reported by Debas (1989) who showed that the sex change occurs during the post spawning and resting period. In addition, using histological observations on material collected during the sex inversion period, the lat- 
ter author identified not only seminiferous cysts, usually found in groupers (Smith, 1965; Reinboth, 1967; Moe, 1969; Bruslé and Bruslé, 1975; De Moussac, 1986; Abu-Hakima, 1987), but also a spermatogonial proliferation which develops throughout the gonad.

The present study deals with the ultrastructural observations on gonads in sex inverting $E$ microdon, with the aim of investigating the origin of germ cells of the heterologous sex.

\section{MATERIALS AND METHODS}

$E$ microdon were caught by diving in the area around Tuamotu (French Polynesia) and kept in the laboratory of Ifremer (COP, Taravao, Tahiti). Gonads were investigated using histological methods (Debas, 1989). For the ultrastructural study we used the same gonads which were fixed by immersion in $3.7 \%$ glutaraldehyde butfered to $\mathrm{pH} 7.3$ with $0.13 \mathrm{M}$ cacodylate buffer for $3 \mathrm{~h}$ at $4{ }^{\circ} \mathrm{C}$. Samples were post-fixed in $2 \%$ osmium tetroxide for $1 \mathrm{~h}$ at $4^{\circ} \mathrm{C}$, dehydrated in a graded acetone series and finally embedded in Epon. Ultrathin sections were stained with uranyl acetate and lead citrate (Reynolds, 1963) and semithin sections $(1 \mu \mathrm{m})$ with methylene blue-Il azur (Richardson et al, 1960).

\section{RESULTS}

Among 222 groupers examined from February 1986 to February 1987, 13 fish (6\%) undergoing sex inversion were identified by the presence of male germ cells in the ovary.

Before and during the spermatogonial proliferation, numerous rather peculiar germ cells were detected (figs 1-3). On semithin sections, these cells can be identified from their strongly basophilic characteristics (figs 1,2 ). At the beginning of the sex change, these germ cells were discernible in the parts of the ovarian lamel- lae lying adjacent to the gonadal wall; later they were observed throughout the lamellae, mixed with spermatogonia and primary spermatocytes (figs 1,2).

Under electron microscope, these germ cells (figs 3,5 ) were characterized by irregular outlines with narrow pseudopodiumlike extensions (fig 4) and by a high electron density related to a finely granular chromatin and many free ribosomes. These cells were oval in shape $(11.6 \mu \mathrm{m} \pm$ 1.36 long $\times 7.6 \pm 1.25$ wide). The voluminous nucleus (nucleus-cell ratio $=0.4 \pm$ 0.13 ) exhibited a nucleolus ( $2 \mu \mathrm{m}$ diameter) containing 2 granular fibrillar components. Membrane organelles (endoplasmic reticulum, golgi complexes, mitochondria) were few in number. Mitochondria (0.4$0.66 \mu \mathrm{m}$ diameter) were very often associated with ciment (cement), forming mitochondrial groupings, which is a dense fibrillar material called nuage (cloud) when independent of mitochondria. This material was characterisitic of germ cells. Moreover, these cells were surrounded by somatic cells which displayed a high nucleocytoplasmic ratio, scarcity of membrane organelles and chromatin found primarily along the inner membrane of the nuclear envelope.

Thus, these germ cells with a high nucleus to cell ratio, abundance of ribosomes and scarcity of membrane organelles exhibited features of undifferentiated cells. Germ cells showing the same ultrastructural characteristics were also identified in undifferentiated gonads (fig 6), juvenile ovaries (fig 7) and testes (fig 8), but they were very few in number in the active gonads. As the cell type recognized in sex inverting gonads was similar to that of differentiating gonads, we suggest that these cells be called 'primordial germ cells' (PGCs). Their ultrastructural identify in both sexes suggested their bipotentiality. Their capacity to differentiate into oogonia or spermatogonia was corroborated by the 

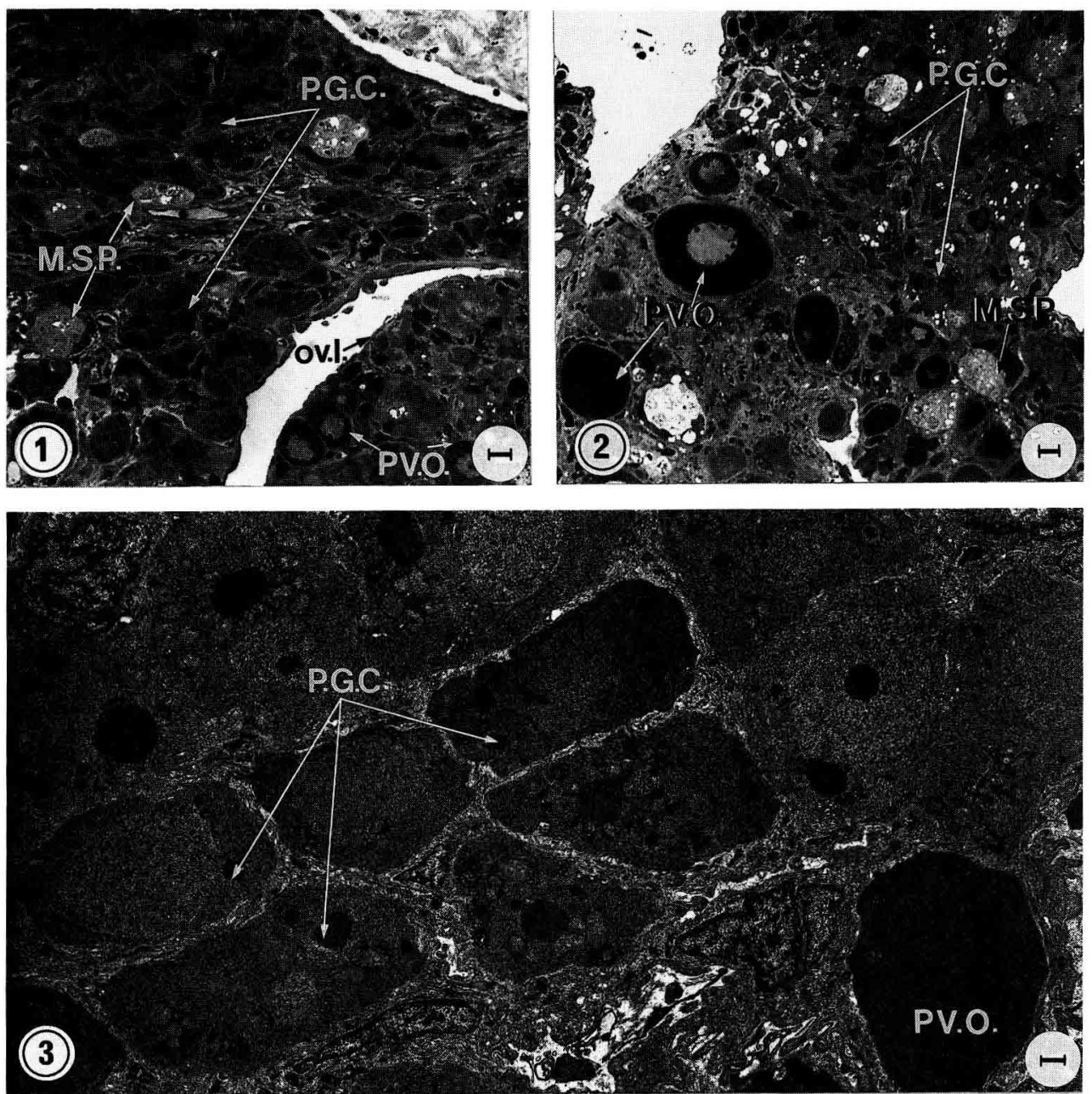

Figs 1-3. 1. Proliferation of PGCs in an ovarian lamella;-_ : $25 \mu \mathrm{m}$. 2. Heterogeneity in an ovarian lamella: PGCs predominant in the upper part of the figure; previtellogenic oocytes still numerous at the bottom of the figure; - : $25 \mu \mathrm{m}$. 3. Numerous PGCs; - $1 \mu \mathrm{m}$. MSP, meiotic spermatocytes; ovl, ovarian lamella; PGC, primordial germ cell; PVO, previtellogenic oocyte.

recognition of intermediate phases between PGCs and oogonia or spermatogonia. The differentiation of PGCs (figs 9,10 ) was characterized by cell outlines becoming more regular, a decreased electron density (owing to a decrease in the num- ber of both chromatin granules and free ribosomes), and increased size of both the cell itself and its nucleus, and an increased number of cytoplasmic organelles. Thus, oogonia (fig 11) and spermatogonia (fig 12) were conspicuously different from 

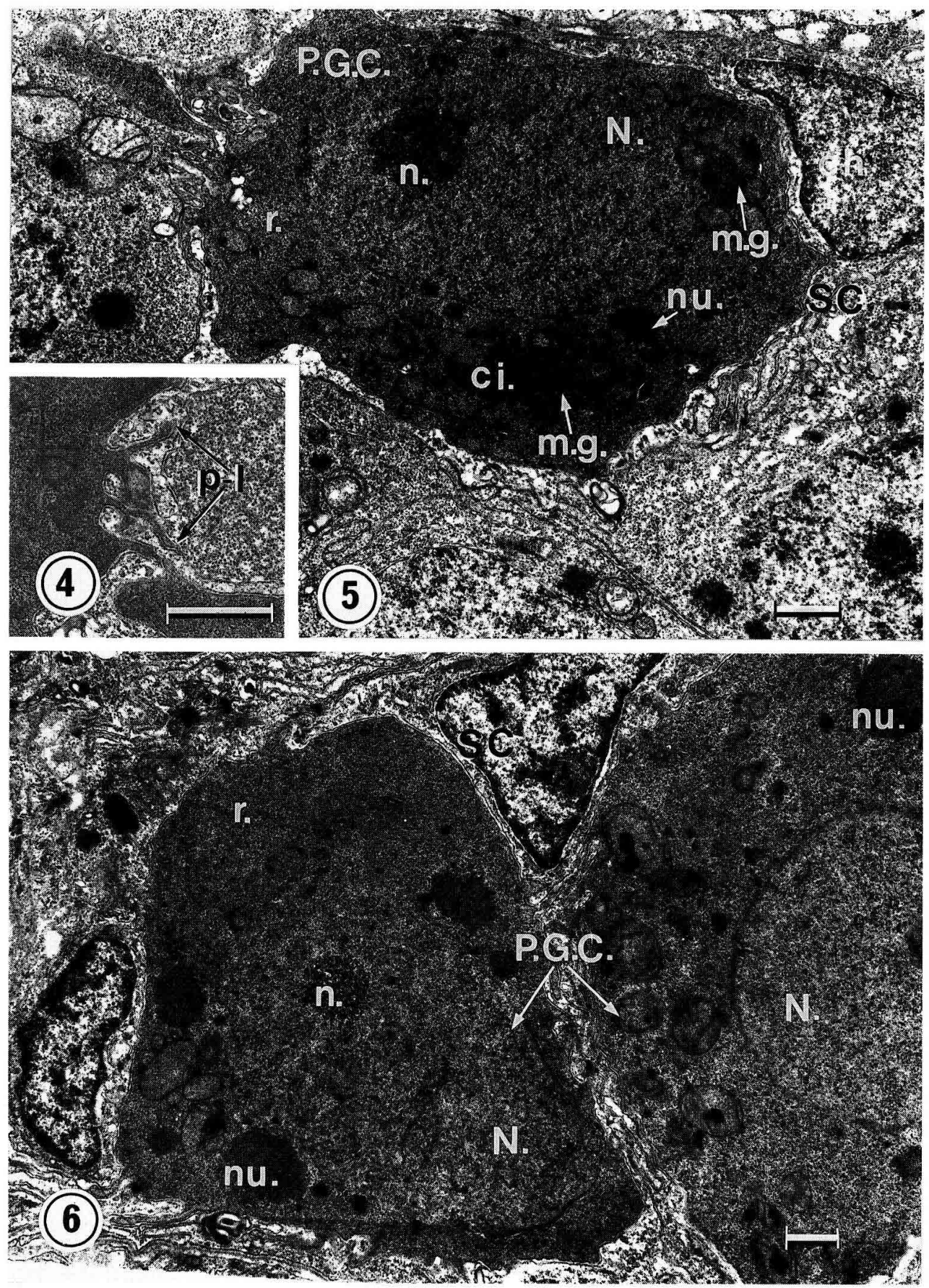

Fig 4-6. 4. A part of a PGC: pseudopodium-like extension; : $1 \mu \mathrm{m}$. 5. PGC, surrounded by a somatic cell; __ : $1 \mu \mathrm{m}$. 6. Juvenile fish: PGCs in an undifferentiated gonad; _- : $1 \mu \mathrm{m}$. ci, ciment (cement); mg: mitochondrial grouping; $N$, nucleus; $n$, nucleolus; nu, nuage (cloud); $p-1$, pseudopodiumlike; PGC, primordial germ cell; r, ribosomes; SC, somatic cell. 

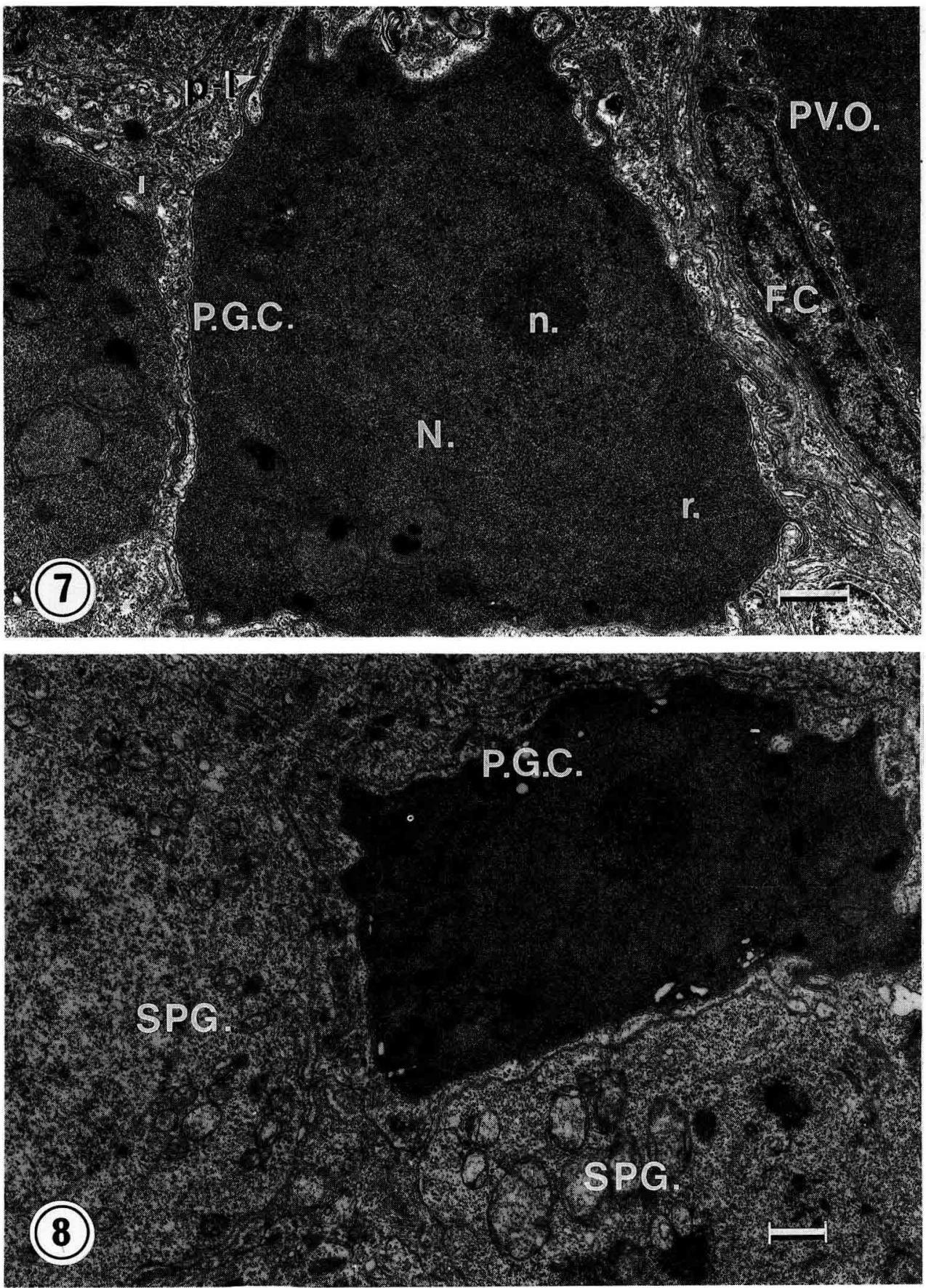

Figs 7-8. 7. PGC in an ovary; : $1 \mu \mathrm{m} .8$. PGC in a testis; $: 1 \mu \mathrm{m} . \mathrm{FC}$, follicle cell; $\mathrm{N}$, nucleus; $n$, nucleolus; PGC, primordial germ cell; $p$-I, pseudopodium-like; PVO, previtellogenic oocyte; $r$, ribosomes; SPG, spermatogonium. 


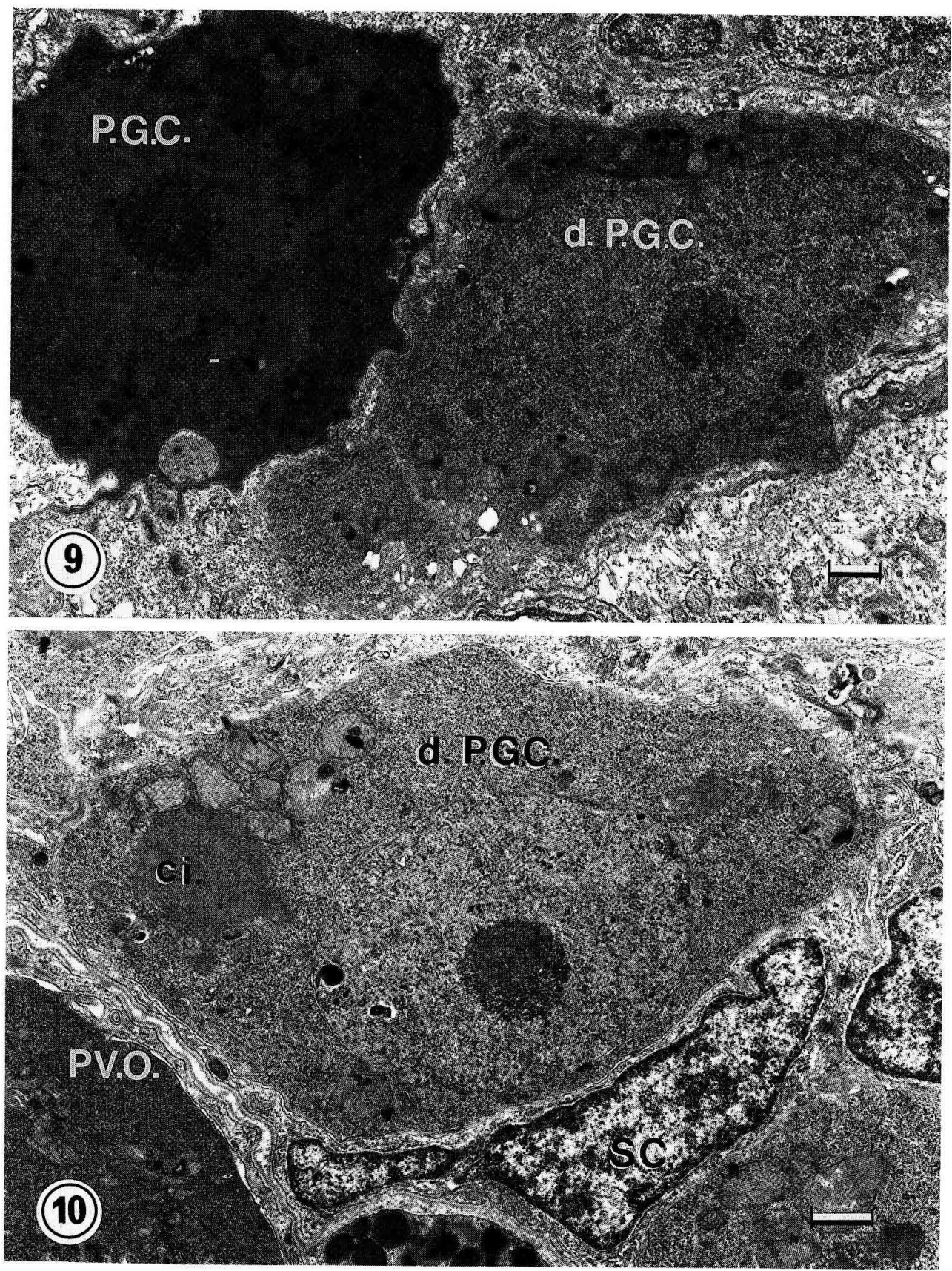

Figs 9-10. 9. Sex inverting gonad: - PGC (on the left of the picture); - differentiating PGC (on the right): less irregular cell outlines, lower electron density than in PGC; - $: 1 \mu \mathrm{m}$. 10. Sex inverting gonad: PGC in late differentiation: nearly regular cell outilines, greater cell size, lower electron density than in PGC; - : $1 \mu \mathrm{m}$. ci, ciment (cement); dPGC, differentiating PGC; PGC, primordial germ cell; $\mathrm{PVO}$, previtellogenic oocytes; SC, somatic cell. 

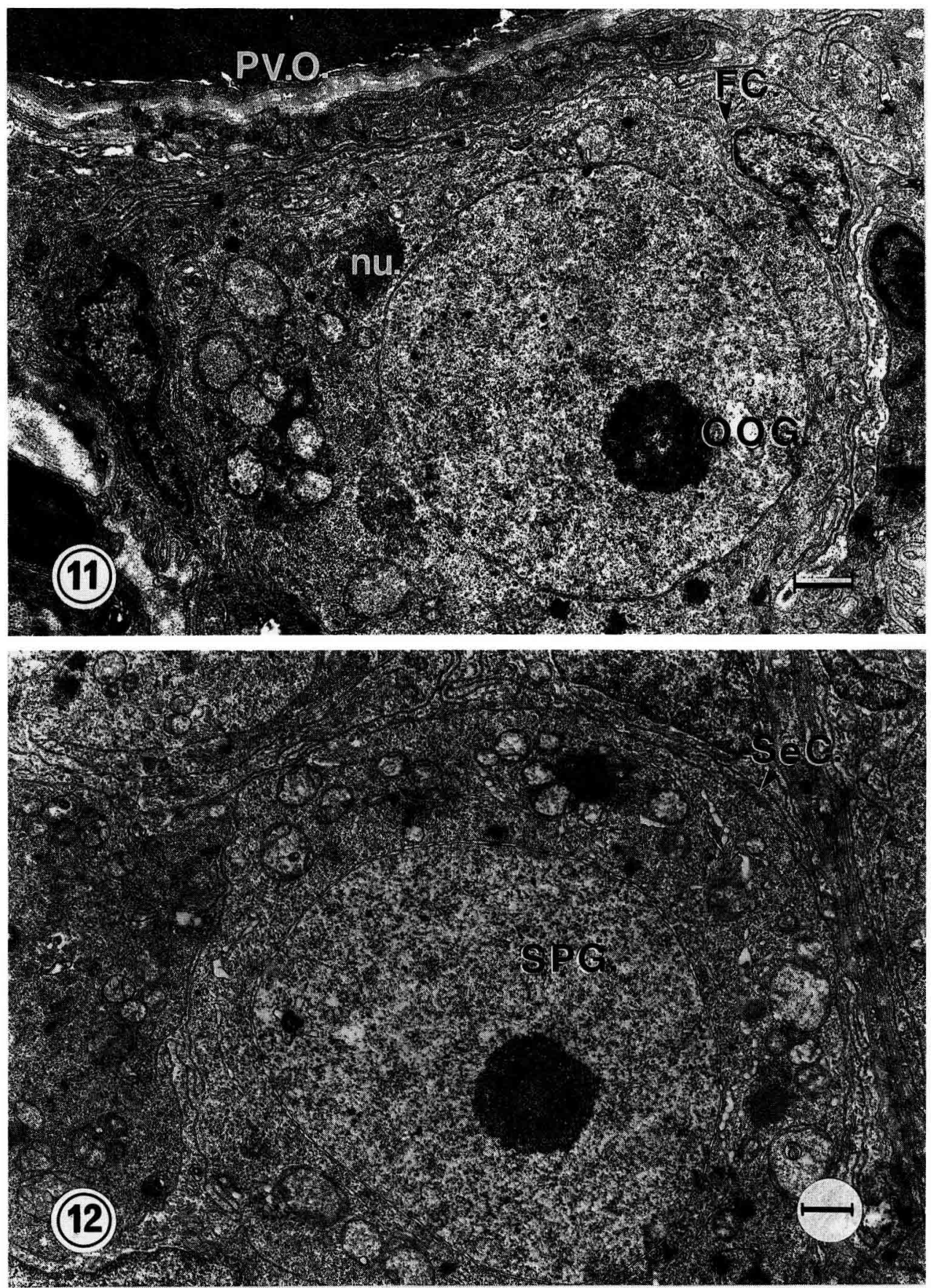

Figs 11-12. 11. An oogonium (in an ovary); : $1 \mu \mathrm{m}$. 12. A spermatogonium (in a testis); $1 \mu \mathrm{m}$. FC, follicle cell; nu, nuage (cloud); OOG, oogonium; PVO, previtellogenic oocyte; SeC, sertoli cell; SPG, spermatogonium. 
PGCs with their regular outlines, low electron density, greater size and with more membrane organelles.

In sex inverting $E$ microdon PGCs and differentiating PGCs were easily identified because they were numerous (fig 3 ), espe- cially during spermatogonial proliferation. Although mitotic activity was observed in spermatogonia (fig 13), similar activity was not recognized in PGCs. However some of them can be contiguous because incompletely surrounded by somatic cells (fig 14).

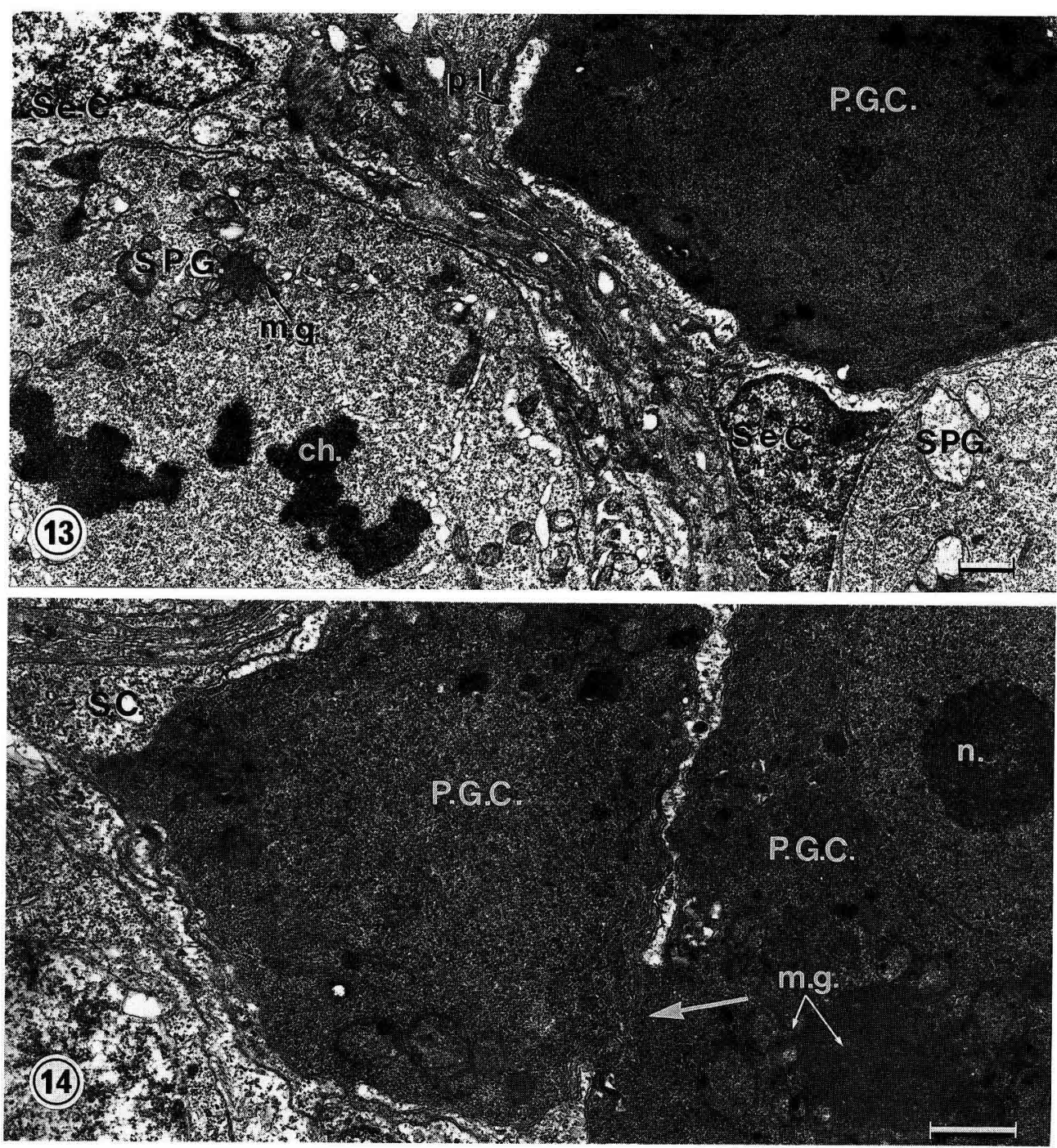

Figs 13-14. 13. Metaphase of a spermatogonium and PGC; - : $1 \mu \mathrm{m} .14$. Incomplete surrounding of PGCs by somatic cells (arrow); — : $1 \mu \mathrm{m}$. ch, chromosomes or chromatin; mg: mitochondrial grouping; $n$, nucleolus; $p-I$, pseudopodium-like; PGC, primordial germ cell; SC, somatic cell; SeC, sertoli cell; SPG, spermatogonium. 
As the sex change proceeded, previtellogenic oocytes became less and less numerous, degenerative processes (vacuoles, broken up cytoplasm, disrupted nuclear organization) were present in some of them and cells endowed with granules became more and more numerous. The latter cells were identified by electron microscope as granulocytes. These immune system cells are characterized by a lobated nucleus and several, large $(0.7 \mu \mathrm{m} \pm 1.75$ long; $0.5 \mu \mathrm{m} \pm 1.32$ wide) homogeneous granules, delimited by a membrane (fig 15). The granulocytes displayed a phagocytic activity (fig 15) in the vicinity of degenerating female germ cells; this activity was corroborated by the presence of digestive vesicles in their cytoplasm (fig 16).

Moreover, in areas of the ovary where spermatogenetic activity could be detected, very small young previtellogenic oocytes were found.

\section{DISCUSSION}

In sex inverting $E$ microdon, in addition to both seminiferous cysts as usually described in groupers (Smith, 1965; Reinboth, 1967; Moe, 1969; Bruslé and Bruslé, 1975; De Moussac, 1986; Abu-Hakima, 1987) and spermatogonial proliferation as recognized by Debas (1989), our investigation revealed the presence of a very large number of strongly basophilic germ cells detected before and during spermatogonial proliferation. Using semithin sections, it was shown that these cells are at first abundant in the parts of ovarian lamellae lying adjacent to the gonadal wall and later throughout the ovarian lamellae, revealing a structural heterogeneity of the gonad.

Our ultrastructural observation on these early germ cells showed that they are characterized by a high nucleus to cell ratio, a high electron density (many chromatin granules and free ribosomes), and rare

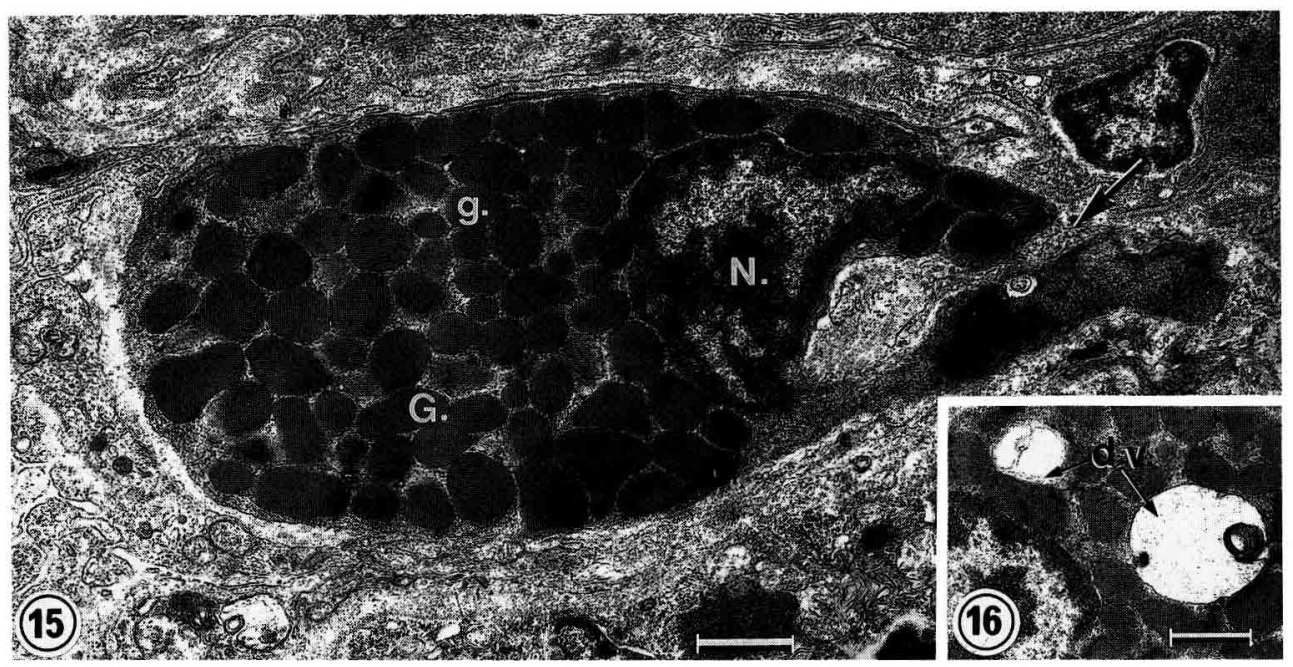

Figs 15-16. 15. A granulocyte in phagocytic activity (arrow); _ : $1 \mu \mathrm{m} .16$. Digestive vesicles in a granulocyte; - $: 1 \mu \mathrm{m}$. dv, digestive vesicle; G, granulocyte; g, granule; N, nucleus. 
membrane organelles. They exhibit features of undifferentiated cells (high nucleocytoplasmic ratio, abundant ribosomes, rare membrane organelles) and are therefore called primordial germ cells (PGCs). Their irregular outlines with narrow pseudopodium-like extensions may be related to amoeboid movements during migration to the gonadal anlagen.

PGCs are generally referred to as the germ cells in undifferentiated gonads. In $E$ microdon we observed PGCs not only in developing gonads but frequently also in sex inverting gonads and, much less frequently, in active ovaries and testes. Similar observations were previously obtained in the protogynous Coris julis (Bruslé, 1987) and the presence of this same cell type was also detected both in developing and in adult specimens of gonochoristic Mugilids (Bruslé and Bruslé, 1978; Bruslé, $1980,1989)$. The cell types described as PGCs in $C$ julis and Mugilids are similar to those investigated in $E$ microdon: irregular outlines, high electron density, high nucleocytoplasmic ratio, rare membranes organelles. The permanent presence of PGCs at every step of sexual development and of the sexual cycle in E microdon suggests that they constitute a germ stock.

The ultrastructural identify of PGCs in gonads of female, male and sex inverting groupers, suggests their bipotentiality and their capacity to differentiate into oogonia or spermatogonia. Several intermediate steps were identified, in which the differentiating germ cells exhibit more and more regular cell outlines, a decrease in electron density (decrease in the number of both chromatin granules and free ribosomes), an increase in cell size and an increase in the number of membrane organelles. Thus, oogonia and spermatogonia appear as regular pale cells which have more membrane organelles than PGCs. Such differentiation of PGCs was previously recognized in Mugil cephalus (Brus- lé, 1980) and in Coris julis (Bruslé, 1987) and similar differences between PGCs and spermatogonia and oogonia were observed in Mugilids (Bruslé, 1989).

The problem of the origin of germ cells of the heterologous sex during the sex inversion of protogynous and some protandric fish was emphasized for a long time (Reinboth, 1970). Some authors postulated the existence of germ cells of the second sex (Moe, 1969; Fujii, 1971; Moore, 1979), others suggested a possible somatic origin (spermatogonia arising from epithelial cells: Dipper and Pullin, 1979; follicle cells transforming into gonocytes: Becker et al, 1975). Two possibilities may be retained. First, the cells involved may be preformed spermatogonia lying dormant in the ovaries of protogynous fish (Coris julis: Reinboth, 1962; Duchac and Buhler, 1983; Labroides dimidiatus: Robertson, 1972; Centropyge: Moyer and Nakazono, 1978; Dascyllus: Shpigel and Fishelson, 1986; Pimelometopon: Warner 1973; Monopterus albus: Chan et al, 1972; Lethrinids: Young and Martin, 1982; $\mathrm{He}$ manthias: Hastings, 1981). Second, the male germ cells may be absent from the active ovaries before the sex inversion (Epinephelids: Moe, 1969; Bruslé, 1982; Thalassoma: Reinboth, 1970; Ross, 1984; Nakamura et al, 1989; Coris julis: Bruslé, 1987) and undifferentiated bipotential cells may be responsible for the male germ line. Some authors call these cells gonia (Reinboth, 1967; Davis 1982) on the grounds that spermatogonia and oogonia are difficult to distinguish as emphasized by Reinboth $(1970,1983)$. For others, the cells involved are protogonia (deutogonia) (McPherson, 1977; Duchac, 1981; Bentivegna and Rasotto, 1983) or gonocytes (Reinboth, 1970; Yeung and Chan, 1987), but they did not describe them (Chan et al, 1975; Duchac, 1981; Bentivegna and Rasotto, 1983; Young and Martin, 1982). Some authors raise the problem of the ex- 
istence of one or two types of bipotential gonocytes (Chan et al, 1975; Yeung and Chan, 1987). After administration of estradiol in the testis of Oryzias latipes, Shibata and Hamaguchi (1988) thought that the oocyte-like cells which were found originated from spermatogonia, which would have to be bipotential. Most previous work related to the origin of germ cells of heterologous sex during the sex inversion has been carried out using light microscopy. Ultrastructural investigations permit the recognition of primordial germ cells (PGCs) both in gonochoristic (Satoh, 1974; Bruslé, 1982, 1989; Hamaguchi, 1982, 1987) and in hermaphroditic fishes (Bruslé, 1983, 1987). In the present work, ultrastructural studies enabled PGCs to be distinguished from oogonia and spermatogonia. We found PGCs in all gonads of $E$ microdon at every step of the sexual cycle. Therefore it seems legitimate to suggest that these cells are bipotential and that only a single type of PGC exists. Their proliferation detected in sex inverting $E$ microdon suggests that PGCs are involved in the testicular ontogenesis which takes place in the ovary during sex inversion. Mitotic activity of PGCs was not discernible but the incomplete surrounding by somatic cells of some of them suggests a possible recent division. Thus, in $E$ microdon the single type of PGCs may retain the sexual bipotentiality up to the onset of sex inversion. Such observations were previously noted in transitional specimens of Coris julis (Bruslé, 1987) during the sex change.

The presence of PGCs that we detected in active ovaries and testes both in gonochoristic (grey mullets: Bruslé, 1989) and in hermaphroditic fishes (Serranus hepatus: Bruslé, 1983; Coris Julis: Bruslé, 1987; $E$ microdon: present paper) has rarely been noted, probably because they are few in number and difficult to observe under light microscope. We suggest that the cell type identified here is the true stem type. Our investigations in Mugilids (Bruslé, 1982) have shown that only oogonia and spermatogonia are involved in the germ cell renewal during the recovery phase. A duality might be suggested among early germ cells, PGCs on the one hand, oogonia and spermatogonia on the other. The successive hermaphroditic fishes show an interesting pattern since in the 'secondary' gonadogenesis which takes place during sex inversion not only gonia but also PGCs are involved.

In gonads of sex inverting groupers, the presence of very small young previtellogenic oocytes detected in the newly formed testicular tissue reveals a possible oogenetic activity which, however, does not proceed beyond the perinucleolar stage. Similar investigations have been reported for $E$ guaza by Bruslé (1982) and for Halichoeres poecilopterus by Reinboth (1988).

Some investigators have suggested that degenerative processes, indicated by atretic oocytes or yellow-brown bodies inside gonadal tissue, signify sex inversion (Moe, 1969; Lissia Frau et al, 1977; De Moussac, 1986; Garrat 1986; Abu-Hakima, 1987). However, the atretic oocytes described by these authors are not always atretic follicles which indicate that vitellogenesis has taken place (Sadovy and Shapiro, 1987). Moreover, brown bodies may be derived from metabolic processes of different tissues and therefore do not constitute a proof of sex inversion (Sadovy and Shapiro, 1987). In sex inverting $E$ microdon, a large number of granulocytes was detected in addition to atretic oocytes. These immune system cells indicate a phagocytic activity towards the female germ cells. The presence of a large number of these cells suggests an implication of the immune system in the degeneration of the female tissue during sex inversion. Such immune cell activity was recently detected during the sex change of Lithognathus mormyrus, a protandrous sparid (Besseau, 1991). 


\section{ACKNOWLEDGMENT}

This work was supported by INRA-IFREMER (CE contract No 85 10178).

\section{REFERENCES}

Abu-Hakima R (1987) Aspects of the reproductive biology of the grouper, Epinephelus tauvina (Forskal), in Kuwaiti water. J Fish Biol 30, 213-222

Atz JW (1964) Intersexuality in fishes. In: Intersexuality in Vertebrates including Man (CN Armstrong, AJ Marshall, eds) Acad Press, NY, 145-232

Becker P, Roland H, Reinboth R (1975) An unusual approach to experimental sex inversion in the teleost fish, Betta and Macropodus. In: Intersexuality in the Animal Kingdom ( $\mathrm{R} \mathrm{Re}$ inboth, ed) Springer Verlag, Berlin, 236-242

Bentivegna F, Rasotto MB (1983) Anatomical features of sex inversion in the rainbow wrasse, Coris julis. Boll Zool 50, 73-78

Besseau $L$ (1991) L'hermaphrodisme protandre chez les Sparidés: Les potentialités de l'ovotestis dans le modèle Lithognathus mormyrus. Thèse doct Univ Perpignan, France, $210 \mathrm{pp}$

Bruslé (1980) Étude ultrastructure des cellules germinales primordiales et de leur différenciation chez Mugil cephalus L 1758 (Téléostéen, Mugilidé). Bull Assoc Anat 64, 207-216

Bruslé S (1982) Contribution à la connaissance de la sexualité de poissons téléostéens marins gonochoriques (Mugilidés) et hermaphrodites (Serranidés). Thèse Doct État, Univ Perpignan, France, 360 pp

Brusle S (1983) Contribution to the sexuality of a hermaphroditic teleost, Serranus hepatus L. J Fish Biol 22, 283-292

Bruslé S (1987) Sex-inversion of the hermaphroditic, protogynous teleost Coris julis L. (Labridae). J Fish Biol 30, 605-616

Bruslé S (1989) Cytological differences in early germ cells of the three genera of grey mullets Mugil, Liza and Chelon (Teleostei, Mugilidae). Zool Sci 6, 789-796

Bruslé J, Bruslé S (1975) Ovarian and testicular intersexuality in two protogynous Mediterra- nean groupers, Epinephelus aeneus and Epinephelus guaza. In: Intersexuality in the Animal Kingdom (R Reinboth, ed) Springer Verlag, Berlin, 222-227

Bruslé S, Bruslé J (1978) An ultrastructural study of early germ cells in Mugil (Liza) auratus Risso, 1810 (Teleostei: Mugilidae). Ann Biol Anim Biochim Biophys 18 (5), 1141-1153

Chan STH, Wai-sum O, Tang F, Lofts B (1972) Biopsy studies on the natural sex reversal in Monopterus albus (Pisces: Teleostei). J Zool (Lond) 167, 415-421

Chan STH, Wai-sum O, Hui SWB (1975) The gonadal and adenohypophysial functions of natural sex reversal. In: Intersexuality in the Animal Kingdom (R Reinboth, ed) Springer Verlag, Berlin, 201-221

Chan STH, Yeung SB (1983) Sex control and sex reversal in fish under natural conditions. In: Fish Physiology IX B (WS Hoar, DJ Randall, EM Donaldson, eds) Acad Press, NY, 171-222

Davis TLO (1982) Maturity and sexuality in Barramundi, Lates calcarifer (Bloch), in the northern territory and south-eastern gulf of Carpentaria. Aust J Mar Freshwater Res 33, 529-545

Debas L (1989) Étude biométrique, histologique et endocrinologique de la sexualité du mérou Epinephelus microdon dans le milieu naturel et en élevage: caractérisation de l'hermaphrodisme protérogyne, description du phénomène d'inversion et mise en évidence du phénomène de réversion. Thèse doct Univ Marseille, France $111 \mathrm{pp}$

De Moussac G (1986) Mise en évidence de I'hermaphrodisme protogyne d'Epinephelus chlorostigma (Valenciennes, 1828) aux Seychelles (Pisces, Serranidae). Cybium 10, 249-262

Dipper FA, Pullin RSV (1979) Gonochorism and sex-inversion in British Labridae (Pisces). $J$ Zool Lond 187, 97-112

Duchac B (1981) Histology and genetic determination of sex-inversion in Coris julis (L). Rapp Comm Int Mer Medit 27, 187-188

Duchac B, Buhler EM (1983) Expression of $\mathrm{H}-\mathrm{Y}$ antigen in the sex-change fish Coris julis. Experientia 39, 767-769

Fujii T (1971) Hermaphroditism and sex reversal in fishes of the Platycephalidae. II. Kumoco- 
cius detrusus and Inegocia japonica. Jpn $J$ IChthyol 18, 109-117

Garrat PA (1986) Protogynous hermaphroditism in the slinger, Chrysoblephus puniceus (Gilchrist and Thompson, 1908) (Teleostei: Sparidae). J Fish Biol 28, 297-306

Hamaguchi S (1982) A light and electron microscopic study on the migration of primordial germ cells in the telost, Oryzias latipes. Cell Tissue Res 227, 139-151

Hamaguchi $S$ (1987) The structure of the germinal dense bodies (nuages) during differentiation of the male germ line of the teleost, Oryzias latipes. Cell Tissue Res 248, 375-380

Hastings PA (1981) Gonad morphology and sex succession in the protogynous hermaphrodite Hemanthias vivanus (Jordan and Swain). J Fish Biol 18, 443-454

Lissia-Frau AM, Pala M, Casu S (1977) Observations and considerations on protandrous hermaphroditism in some species of Sparid fishes (Teleostei, Perciformes). Stud Sassar $54,147-167$

Loubens G (1980) Biologie de quelques espèces de poissons du lagon néocalédonien. II. Sexualité et reproduction. Cah IndoPacifique 2, 41-72

McPherson GR (1977) Sex change in the wrasse Pseudolabrus gymnogenis (Labridae). Aust Zool 19, 185-200

Moe MA (1969) Biology of the red grouper Epinephelus morio (Val) from the eastern gulf of Mexico. Florida Dept Nat Res St Petersb 10, 1-95

Moore R (1979) Natural sex inversion in the giant perch (Lates calcarifer). Aust I Mar Freshwater Res 30, 803-813

Moyer JT, Nakazono A (1978) Population structure, reproductive behavior and protogynous hermaphroditism in the Angelfish Centropyge interruptus at Miyake-jima Japan. Jpn J /chthyol 25, 25-39

Nakamura M, Hourigan TF, Yamauchi K, Nagahama Y, Grau EG (1989) Histological and ultrastructural evidence for the role of gonadal steroid hormones in sex change in the protogynous wrasse, Thalassoma duperrey. Environ Biol Fish 24, 117-136

Reinboth R (1962) Morphologische und funktionelle Zweigeschlechtlichkeit bei marinen Tel- eostiern (Serranidae, Sparidae, Centracanthidae, Labridae). Zool Jb Physiol 69, 405-480

Reinboth R (1967) Protogynie bei Chelidoperca hirundinacea (Cuv et Val) (Serranidae). Ein Diskussionsbeitrag zur Stammesgeschichte amphisexueller Fische. Annot Zool Jpn 40, $181-186$

Reinboth $R$ (1970) Intersexuality in fishes. Mem Soc Endocr GB 18, 515-543

Reinboth R (1983) Gonadal sex reversal. Differentiation 23 (suppl), S82-S86

Reinboth R (1988) Physiological problems of teleost ambisexuality. Environ Biol Fish 22, 249-259

Reynolds ES (1963) The use of lead citrate at high $\mathrm{pH}$ as an electron opaque stain in electron microscopy. J Biophys Biochem Cytol $17,208-212$

Richardson KC, Jarett L, Finke EH (1960) Embedding in epoxy resin for ultrathin sectioning in electron microscopy. Stain Technol 35, 313-323

Robertson DR (1972) Social control of sex reversal in a coral fish. Science 177, 10071009

Ross RM (1984) Anatomical changes associated with sex reversal in the fish Thalassoma duperrey (Teleostei: Labridae). Copeia $t$, 245-248

Sadovy Y, Shapiro DY (1987) Criteria for the diagnosis of hermaphroditism in fishes. Copeia $1,136-156$

Satoh N (1974) An ultrastructural study of sex differentiation in the Teleost. Oryzias latipes. $J$ Emb Exp Morph 32, 195-215

Shibata N, Hamaguchi S (1988) Evidence for the sexual bipotentiality of spermatogonia in the fish, Oryzias latipes. J Exp Zool 245, 7177

Shpigel M, Fishelson L (1986) Behavior and physiology of coexistence in two species of Dascyllus (Pomacentridae, Teleostei). Environ Biol Fish 17, 253-265

Smith CL (1965) The patterns of sexuality and the classification of Serranid fishes. Am Mus Nat Hist 2207, 1-20

Smith CL (1971) A revision of the American groupers: Epinephelus and allied genera. Bull Am Mus Nat Hist 146, 67-242 
Wamer RR (1973) Ecological and evolutionary aspects of hermaphroditism in the California sheephead Pimelometopon pulchrum (Ayres). Contrib Univ Calif San Diego 43, 1811-1812

Yeung WSB, Chan STH (1987) The gonadal anatomy and sexual pattern of the protan- drous sex-reversing fish, Rhabdosargus sarba (Teleostei: Sparidae). J Zool (Lond) 212, 521-532

Young PC, Martin RB (1982) Evidence for protogynous hermaphroditism in some lethrinid fishes. J Fish Biol 21, 475-484 